\title{
The glpT and glpQ genes of the glycerol regulon in Bacillus subtilis
}

\author{
Rune-Pär Nilsson, Lena Beijer and Blanka Rutberg
}

Author for correspondence: Rune-Pär Nilsson. Tel: +4646 108631. Fax +46 46157839.

Department of Microbiology, Lund University, Sölvegatan 21, S-223 62 Lund, Sweden

\begin{abstract}
The cloning of the Bacillus subtilis glpT and glpQ genes and their nucleotide sequences are reported. Analysis of mRNA indicates that glpT and glpQ constitute one operon which is transcribed from a sigma $A$ type promoter. The steady state amount of gIpTQ mRNA is increased in cells grown in the presence of glycerol 3-phosphate. The 5' untranslated leader sequence of gIpTQ mRNA contains an inverted repeat which shows sequence similarity to repeats present in the leader sequences of gIpFK and gIpD transcripts. These repeats seem therefore to be essential control elements for all B. subtilis glp genes.
\end{abstract}

Keywords: Bacillus subtilis, glycerol regulon, glp $T$ gene, $g l p Q$ gene

\section{INTRODUCTION}

Genes of the $B$. subtilis glp regulon are involved in catabolism of glycerol and glycerol 3-phosphate (G3P). The known glp genes map at two locations on the bacterial chromosome, $15^{\circ}$ and $75^{\circ}$. We have previously reported the cloning of the four $g / p$ genes located at $75^{\circ}$ and their nucleotide sequences (Holmberg \& Rutberg, 1989; Holmberg et al., 1990; Beijer et al., 1993). These genes are: $g l p P$, encoding a positively acting regulatory protein; $g l p F$, encoding a glycerol uptake facilitator; $g l p K$, encoding glycerol kinase; and $g / p D$, encoding an NADindependent G3P dehydrogenase. The four genes represent three operons: $g l p P, g l p F K$ and $g l p D . g l p F K$ and $g l p D$ are induced by G3P. A conserved inverted repeat is found in the $5^{\prime}$ untranslated leader sequences of $g l p F K$ and $g l p D$ mRNA, respectively. This repeat has been shown to be a conditional signal for termination of the $g l p D$ transcript and the GlpP protein is proposed to increase transcription across the inverted repeat in induced cells (Holmberg \& Rutberg, 1991, 1992). The activities of, e.g., the $B$. subtilis sacP $A$ and $\operatorname{sac} B$ operons (Crutz et al., 1990; Débarbouillé $e t$ al., 1990) and the E. coli bgl system (Houman et al., 1990) are controlled in a way similar to the glpD activity. However, the regulatory proteins and their targets in the $s a c$ and $b g l$ systems are not related at the sequence level to GlpP and the B. subtilis glpD

Abbreviations: Ap, ampicillin; C230, catechol-2,3-dioxygenase; rbs, ribosome binding site; $\mathrm{Cm}$, chloramphenicol; G3P, glycerol 3-phosphate; Tc, tetracycline.

The EMBL accession number for the nucleotide sequence reported in this paper is Z26522. inverted repeat, respectively. The glp genes are subject to glucose repression but the mechanism is not understood.

The activity of the Eschericbia coliglp genes is controlled by a repressor protein, the product of the $g / p R$ gene (Schweizer et al., 1985). Binding of G3P to the repressor decreases its affinity for its operators, leading to induction of the glp genes. More than ten glp genes have been identified in E. coli (Lin, 1987; Truniger et al., 1992). Among these the $g l p T Q$ operon encodes a G3P permease and a phosphodiesterase which hydrolyses glycerophosphoryl diesters into G3P plus alcohol (Eiglmeier et al., 1987; Tommassen et al., 1991). The permease acts as a G3P-phosphate anionic antiport (Maloney et al., 1990); it may also have a role in phosphate metabolism under some conditions (Brzoska et al., 1987; Larson, 1987). The $B$. subtilis $g l p T$ gene maps at $15^{\circ}$. GlpT mutants fail to grow with G3P as a sole carbon source and are defective in uptake of G3P (Lindgren, 1978). GlpP mutants are also defective in uptake of G3P in addition to being noninducible for the $g l p F K$ and $g l p D$ products. Consequently, they cannot grow on either G3P or glycerol as a sole carbon source.

In the present communication we report the cloning of $B$. subtilis $g l p T$. Sequencing of the $g l p T$ region has revealed a gene downstream of $g l p T$ which we propose to be $g l p Q$ on basis of its similarity to E. coliglpQ. Analysis of transcripts shows that $g l p T Q$ is one operon. The $5^{\prime}$ untranslated leader sequence of the $g l p T Q$ mRNA contains an inverted repeat with strong similarity to those present in $g l p F K$ and $g l p D$ mRNA. Such a repeat thus seems to be an essential control element for $B$. subtilis glp genes. 
Table 1. Bacterial strains and plasmids

\begin{tabular}{|c|c|c|}
\hline Strain/plasmid & Genotype/phenotype & Source/reference \\
\hline \multicolumn{3}{|l|}{ B. subtilis } \\
\hline BR95 & ilv $C 1$ phe $A 1$ trpC 2 & Our collection \\
\hline KA6 & $\begin{array}{l}g l p T 1 \text { (previously referred to as } \\
p h m 2 a) \text { phe } A 1\end{array}$ & Lindgren (1978) \\
\hline \multicolumn{3}{|l|}{ E. coli } \\
\hline MM294 & pro thi end $A b s r_{\mathbf{k}} b s r_{\mathrm{m}+}$ & Amann et al. (1983) \\
\hline \multicolumn{3}{|l|}{ Plasmids } \\
\hline pHP13 & $\mathrm{Cm}^{\mathrm{R}} \mathrm{Em}^{\mathrm{R}}$ & Haima et al. (1987) \\
\hline pHV32 & $\mathrm{Ap}^{\mathrm{R}} \mathrm{Cm}^{\mathrm{R}} \mathrm{Tc}^{\mathrm{R}}$ & Niaudet et al. (1982) \\
\hline pBluescript II $\mathrm{KS}(-)$ & $A p^{R}$ & Stratagene \\
\hline pAMB22 & $\mathrm{Cm}^{\mathrm{R}} \mathrm{Tc}^{\mathrm{R}} \mathrm{XylE}^{-}$ & Zukowski \& Miller (1986) \\
\hline pLUM2 & $g l p T^{+} \mathrm{Ap}^{\mathrm{R}} \mathrm{Cm}^{\mathrm{R}} \mathrm{Tc}^{\mathrm{R}}$ & This work \\
\hline pLUM5 & internal $g l p T$ fragment, $A p^{\mathrm{R}}$ & This work \\
\hline pLUM620 & $g l p T$ promoter, $\mathrm{XylE}^{+} \mathrm{Cm}^{\mathrm{R}} \mathrm{Tc}^{\mathrm{R}}$ & This work \\
\hline pLUM621 & $g l p T$ promoter, $\mathrm{XylE}^{+} \mathrm{Cm}^{\mathrm{R}} \mathrm{Tc}^{\mathrm{R}}$ & This work \\
\hline
\end{tabular}

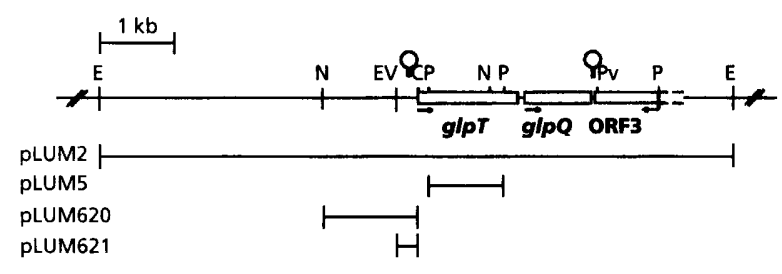

Fig. 1. Schematic representation of the glpTQ region of the $B$. subtilis chromosome. The positions of inverted repeats are indicated with hairpin symbols. Arrows indicate direction of transcription. The chromosomal DNA fragment present in each plasmid is shown. The vector parts are: pHV32 in pLUM2; pBluescript II KS(-) in pLUM5; pAMB22 in pLUM620 and pLUM621. C, Cfr10l; E, EcoRI; EV, EcoRV; N, Nael; P, Pstl; Pv, Pvull. Restriction endonuclease sites shown are not necessarily unique. The nucleotide sequence was determined from $600 \mathrm{bp}$ upstream of $g / p T$ to $800 \mathrm{bp}$ downstream of glpQ. Both strands were sequenced and all restriction sites fully overlapped. The nucleotide sequence between EV-PV is presented in Fig. 2 . Plasmid pLUM620 was constructed as follows: a $2.3 \mathrm{~kb}$ Sacl-Kpnl DNA fragment (including the Nael-Nael fragment and a few extra bp from the cloning cassette of pBluescript) was taken from a plasmid containing the Nael fragment inserted in the EcoRV site of pBluescript II KS(-). The Sacl-KpnI fragment was digested with Cfr10l and made blunt-end with Klenow enzyme. After digestion with EcoRI, the fragment was ligated to PAMB22 that had been cleaved with EcoRI and Smal.

\section{METHODS}

Strains and plasmids. Bacterial strains and plasmids used in this work are listed in Table 1.

Media. Bacterial strains were kept on Tryptose Blood Agar Base plates. For preparation of plasmid DNA the bacteria were grown in Luria Broth. The minimal salts solution was that of Anagnostopoulos \& Spizizen (1961). When cells were kept on minimal plates containing G3P as the sole energy and carbon source, a minimal medium with no phosphate was used (Garen \& Levinthal, 1960). When appropriate, the following additions were made: glucose, $5 \mathrm{~g} \mathrm{l}^{-1}(30 \mathrm{mM})$; glycerol, $20 \mathrm{mM}$;
DL- $\alpha-G 3 P, 40 \mathrm{mM}$; Casamino acids, $5 \mathrm{~g} \mathrm{l}^{-1}$. Antibiotics were added to the following concentrations: ampicillin (Ap), $50 \mathrm{mg} \mathrm{l}^{-1}$; chloramphenicol $(\mathrm{Cm}), 5 \mathrm{mg} \mathrm{l}^{-1}$ (B. subtilis) or $12.5 \mathrm{mg} \mathrm{l}^{-1}$ (E. coli); tetracycline (Tc), $10 \mathrm{mg} \mathrm{l}^{-1}$.

Transformation. Competent B. subtilis cells were prepared as described by Arwert \& Venema (1973). E. coli cells were made competent as described by Mandel \& Higa (1970).

DNA techniques. Chromosomal DNA was prepared essentially as described by Marmur (1961). Plasmid DNA from E. coli was prepared using the boiling method of Ausubel et al. (1987) (mini preparations) or Qiagen (Diagen; maxi preparations). Plasmid DNA from B. subtilis was prepared using Magic Maxipreps (Promega). DNA fragments separated on agarose gels were purified using Geneclean (Bio 101 Inc.).

Cloning procedure. Plasmid pHV32 replicates in E. coli but not in $B$. subtilis. It carries a cat gene which is expressed in both $E$. coli and $B$. subtilis. Variants of pHV32 which carry fragments of $B$. subtilis chromosomal DNA can transform $B$. subtilis to $\mathrm{Cm}^{\mathrm{R}}$ by integrating into the bacterial chromosome by homologous recombination. Plasmid pHV32 carrying B. subtilis chromosomal DNA can be regenerated in E. coli (Niaudet $e t$ al., 1982) by cleaving chromosomal DNA with an appropriate restriction enzyme, followed by ligation and then transformation of $E$. coli selecting for antibiotic resistance.

B. subtilis BR95 DNA and pHV32 were cleaved with EcoRI, mixed and ligated. B. subtilis KA6 (glpT1) was transformed to $\mathrm{Cm}^{\mathrm{R}}$ with the ligate. About $0 \cdot 1 \%$ of the $\mathrm{Cm}^{\mathrm{R}}$ transformants grew on G3P as a sole carbon and energy source, showing that they had been transformed for the $g l p T$ marker also. DNA from three such transformants, carrying pHV32, was used to transform B. subtilis $\mathrm{KA} 6$ to $\mathrm{Cm}^{\mathrm{R}}$. Between $75 \%$ and $85 \%$ of the $\mathrm{Cm}^{\mathrm{R}}$ transformants were also $\mathrm{GlpT}^{+}$, showing that $\mathrm{pHV} 32 \mathrm{had}$ integrated close to $g l p T$. From two of the three transformants carrying pHV32, variants could be selected which grew in the presence of at least $40 \mu \mathrm{g} \mathrm{Cm} \mathrm{ml}{ }^{-1}$. This indicates that $\mathrm{pHV} 32$ has integrated by the Campbell mode and is flanked by a duplication of the fragment used for integration (Young, 1984). pHV32 and adjacent chromosomal DNA was regenerated from one of these two transformants. Chromosomal DNA from the 
transformant was cleaved with different restriction endonucleases, ligated and used to transform Escherichia coli MM294 to $A p^{R}, \mathrm{Cm}^{\mathrm{R}}$ or $\mathrm{Tc}^{\mathrm{R}}$. Plasmid DNA was prepared from the transformants and used to transform $B$. subtilis KA6 selecting for $\mathrm{Cm}^{\mathrm{R}} \cdot \mathrm{Cm}^{\mathrm{R}}$ transformants were then checked for growth on G3P. Two plasmids generated by $B g / I I$ and $S p h I$ cleavage, respectively, yielded $\mathrm{Cm}^{\mathrm{R}}$ transformants of which $90 \%$ grew on G3P and thus carried the wild-type allele of $g l p T$. The plasmid called pLUM2 (Fig. 1), obtained with $B g l \mathrm{II}$, was used for further work. It contains the wild-type allele of $g l p T 1$ on an $8.6 \mathrm{~kb}$ fragment. Further subcloning showed that the wild-type allele of glp T1 is located on a $1 \mathrm{~kb}$ Pst fragment (pLUM5, Fig. 1).

DNA sequence analysis. Nucleotide sequences were determined by the dideoxy chain-termination method of Sanger et al. (1977), using Sequenase version 2.0 (United States Biochemical Corp.) and $\left[\alpha-{ }^{35}\right.$ S $]$ dATP. Templates used were DNA fragments cloned into $\mathrm{pHV} 32$ or pBluescript II $\mathrm{KS}(-)$. Primers used were universal or specific for the B. subtilis chromosomal DNA being sequenced. Nucleotide sequences were analysed using the GCG Sequence Software Package (Devereux et al., 1984).

Preparation of cell free extracts and assay of catechol-2,3dioxygenase (C230). Cell-free extracts were prepared as described by Lindgren \& Rutberg (1974). C23O activity was measured as described by Sala-Trepat \& Evans (1971).

RNA preparation. Bacteria were grown to $\mathrm{OD}_{600}=0.3$ at $37^{\circ} \mathrm{C}$ on a rotary shaker $(200$ r.p.m.) in minimal salts solution supplemented with Casamino acids and, when appropriate, $\mathrm{Cm}$. The cultures were then divided into two parts. To one part, G3P $(40 \mathrm{mM})$ was added and to the other part no addition was made. The cultures were further incubated at $37^{\circ} \mathrm{C}$ for $1 \mathrm{~h}$ and total RNA was then extracted as described by Resnekov et al. (1990).

Nuclease S1 mapping. Nuclease S1 mapping was done as described by Sambrook et al. (1989). A sample $(0 \cdot 4 \mu \mathrm{g})$ of probe labelled at the $5^{\prime}$ end was mixed with $40 \mu \mathrm{g}$ of total RNA. After hybridization overnight at $46^{\circ} \mathrm{C}$, each sample was divided in two and one part was treated with $300 \mathrm{U}$ nuclease $\mathrm{S} 1 \mathrm{ml}^{-1}$ for $1.5 \mathrm{~h}$ at $37^{\circ} \mathrm{C}$. Half of each sample was analysed by electrophoresis on a polyacrylamide gel $(6 \%, \mathrm{w} / \mathrm{v}$, acrylamide, $0.3 \%$, $\mathrm{w} / \mathrm{v}$, bisacrylamide) containing $7 \mathrm{M}$ urea. A known DNA sequence was used as a size marker.

Northern analysis. Northern blot and hybridization analysis was performed according to the protocols of Amersham. RNA was blotted onto Hybond-N membranes (Amersham). ${ }^{32} \mathrm{P}$ labelled probes were synthesized using a random primed DNA labelling kit (Boehringer Mannheim) and $\left[\alpha^{32} \mathrm{P}\right] \mathrm{dCTP}$ [>3000 $\mathrm{Ci} \mathrm{mmol}^{-1}\left(111 \mathrm{TBq} \mathrm{mmol}{ }^{-1}\right)$; Amersham]. RNA molecular mass markers (Bethesda Research Laboratories) were used to estimate the size of transcripts.

\section{RESULTS AND DISCUSSION}

\section{Nucleotide sequence of the $g / p T$ and $g / p Q$ genes}

The wild-type allele of $g l p T 1$ was cloned on an $8.6 \mathrm{~kb}$ fragment of chromosomal $B$. subtilis DNA generating plasmid pLUM2 as described in Methods. DNA sequence analysis of about $3700 \mathrm{bp}$ in pLUM2, including the $1 \mathrm{~kb}$ PstI fragment containing the wild-type allele of $g l p T 1$, revealed three open reading frames (ORFs; Figs 1 and 2). The first ORF, which includes the $1 \mathrm{~kb}$ Pst I fragment, can encode a protein of 444 amino acids with a molecular mass of $50 \mathrm{kDa}$. The proposed protein shows $60 \%$ identity with the E. coli G3P permease (Fig. 3). This high level of identity with the $E$. coli G3P permease, together with the fact that a mutation which impairs uptake of G3P in $B$. subtilis maps within this ORF, identifies it as $g l p T$. Preceding $g l p T$ by $10 \mathrm{bp}$ is a typical ribosome binding site (rbs; Fig. 2). A hydropathy plot of B. subtilis GlpT (not shown) reveals several hydrophobic, potential membrane spanning segments and it is very similar to that reported for E. coli GlpT (Eiglmeier et al., 1987). The E. coli protein has been proposed to contain 12 membrane spanning segments (Gött \& Boos, 1988).

The second ORF starts with an ATG 101 bp downstream of the TAA stop codon of $g l p T$. It can encode a protein of 293 amino acids with a molecular mass of $33 \mathrm{kDa}$. The sequence of the proposed protein shows $37 \%$ identity with the E. coli GlpQ, a periplasmic glycerophosphoryl diester phosphodiesterase (Fig. 4). The similarity between the two sequences is particularly strong in the aminoterminal region which has been suggested to harbour the catalytic site of E. coli GlpQ (Tommassen et al., 1991). The first 26 amino acids may constitute a signal peptide containing three positively charged amino acid residues, a hydrophobic core and a putative cleavage site between two alanines. These features are common among many known B. subtilis signal peptides. B. subtilis homologues of E. coli periplasmic proteins are often lipoproteins but this is not the case for B. subtilis GlpQ (Nagarajan, 1993). In $E$. coli, glpT and $g l p Q$ form one operon. In B. subtilis, glp $T$ and the downstream ORF seem to constitute one operon (see later). From the above facts we propose that the ORF downstream of $B$. subtilis $g l p T$ is the $g l p Q$ gene. $g l p Q$ is preceded by a possible rbs (Fig. 2).

Downstream of B. subtilis glpQ, we have found part of a third open reading frame (corresponding to 286 amino acids). This ORF3 has the opposite orientation relative to $g l p T$ and $g l p Q$. No protein with a sequence similar to the partial sequence of the proposed ORF3 protein has been found in searches of the EMBL data bank (Release 32.0804).

A well-conserved sigma A type (Gross et al., 1992) - 10 sequence, GATAAT, is located $160 \mathrm{bp}$ upstream of the proposed $g l p T$ ATG start codon. At $15 \mathrm{bp}$ upstream of this sequence a typical -35 sequence, TTTACA, is found. Four bp downstream of the proposed -10 sequence is a sequence where $13 / 14 \mathrm{bp}$ conform to the 'glucose repression sequence' proposed by Weickert \& Chambliss (1990). Similar sequences have been found also upstream of $B$. subtilis $g l p P, g l p F K$ and $g l p D$, respectively. $A$ role for these sequences in glucose repression of the $B$. subtilis glp regulon has not been demonstrated, however.

An inverted repeat (position 202-248, Fig. 2) is found between the proposed promoter and the glp $T$ coding region. This inverted repeat shows sequence similarity to the previously identified inverted repeats (Fig. 5) in the non-coding regions upstream of $g l p D$ and $g l p F K$, respectively (Holmberg et al., 1990; Beijer et al., 1993). The similarities extend to upstream of the inverted repeats. The importance of the control regions (promoter and 


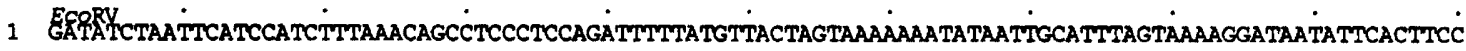

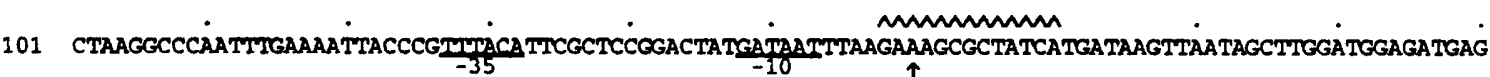
201 GAGAGCCAGGAATCCAACCCCTTITGACAAGGGGTGTPITCTGGCTCITTTTGTTTTOGGGAAGGAGGCACGCCACACATCCAGCACAAACAGCAAAG

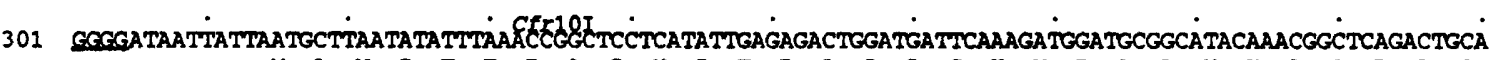

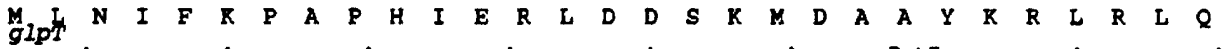

401 AGTATTCATTGGTATTTICATTGGCTACGCAGGCTACTACCTGCTGCGGAAAAACTTTGCCTTTGCCATTCCTTATREFGLAGGAACAGGGATTTTCGAAA $\begin{array}{llllllllllllllllllllllllllllllllll}V & F & I & G & I & F & I & G & Y & A & G & Y & Y & L & L & R & K & N & F & A & F & A & I & P & Y & L & Q & E & Q & G & F & S & K\end{array}$

501 ACAGAACTGGGTTGGTGCTGGCCGCTGTǴTCCATTGCGTACGGCTICAGCAAATTCATCATGGGAATGGTGTCTGACCGCTGTAATCCGAGATATTTTC $\begin{array}{lllllllllllllllllllllllllllllllllll}T & E & L & G & L & V & L & A & A & V & S & I & A & Y & G & F & S & \mathbb{X} & F & I & G & G & M & V & S & D & R & C & N & P & R & Y & F & L\end{array}$

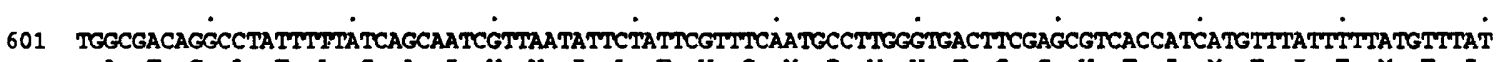
$\begin{array}{llllllllllllllllllllllllllllllllll}\text { A } & T & G & L & F & L & S & A & I & V & N & I & L & F & V & S & M & P & W & V & T & S & S & V & T & I & M & F & I & F & M & F & I\end{array}$

701 CAACGGATGGTTTCAAGGAATGGGCTGGCCGCCATGCGGCAGGACGATGGCCCATTGGTTCTCCATAAGTGAACGCGGCACAAAAATGTCGATCTGGAAT

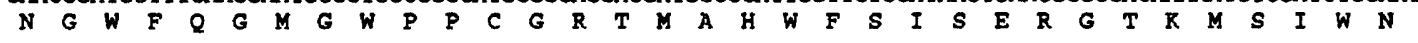

801 GICGCCCATAACATAGGCGGCGGTATTCTIGCTCCGCTTGTTCACTCTTGGGATCGCGATGTTCGTCACTTGGAAAAGCGTGTTTTTCTTCCCTGCCATCA

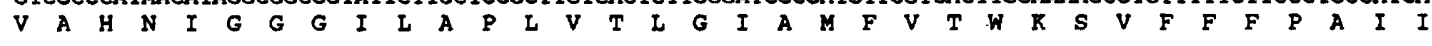

901 TCGCCATTATCATTTCATTITTAATTGTTITATTGGTTCGTGATACGCCTCAATCCTGCGGACTCCCGCCAATTGAAGAGTATCGGATGACTATCCAAA $\begin{array}{lllllllllllllllllllllllllllllllll}A & I & I & I & F & L & I & V & L & L & V & R & D & T & P & Q & S & C & G & L & P & P & I & E & E & Y & R & N & D & Y & P & R\end{array}$

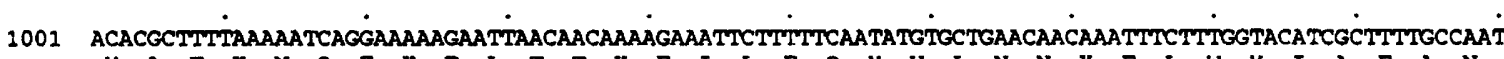

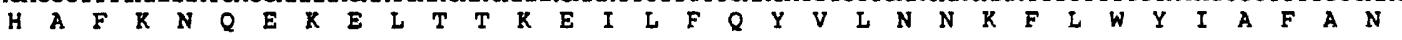

1101 GTATTMTIPATTICGTGCGATACGGCGTGGTTGACTGGGCGCCTACTTACTTAACAGAAGCCAAAGGCTITTCTCCTGAAGACTCACGCTGGTCGTATT $\begin{array}{lllllllllllllllllllllllllllllllllllll}V & F & V & Y & F & V & R & Y & G & V & V & D & W & A & P & T & Y & L & T & E & A & K & G & F & S & P & E & D & S & R & W & S & Y & F\end{array}$

1201 TTCTTTACGAATACGCAGGCATACCGGGAACGATCTTGTGCGGCTGGATCAGTGACCGATTTTTCAAAAGCCGCCGGGCACCGGCAGGCGTTTTGTTTAT $\begin{array}{llllllllllllllllllllllllllllllllll}L & Y & E & Y & A & G & I & P & G & T & I & L & C & G & W & I & S & D & R & F & F & K & S & R & R & A & P & A & G & V & L & F & M\end{array}$

1301 GGCGGGTGTTPTCATIGCCGTATTGGTGTACTGGCTGAATCCGNGEIGCAATCCGCTCGTGGACAATATCGCCCTGATCAGCATTGGCTTCTTAATCTAC

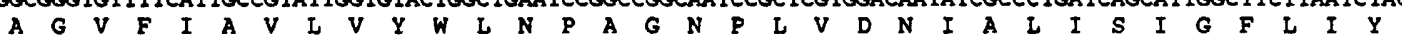

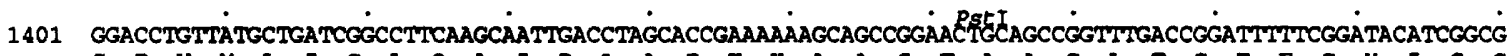

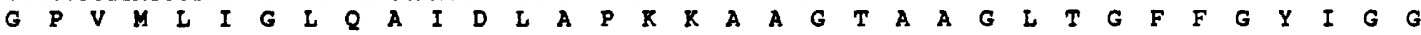

1501 GATCCGCCITICGCAAACGCCATTATGGGCTTTGTCGTGGACCGTTTTAACTGGAACGGCGGCTTTATCATGCTGATCTCATCCTGCATTCTTGCCATCGT

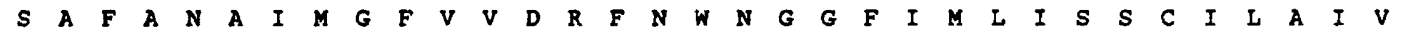

1601 CTTCTTGGCTITTGACGTGGAATACAGGAAAACGGGCAGAGCATGTTTAAGAAAGACACATAAAAGATTAAंTAGTITICCAACACGCCGTITACATCCGTT F L A L T W N T G R R A E H V *

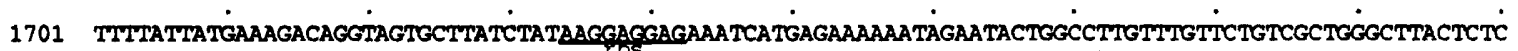
$\begin{array}{llllllllllllllllllll}M & \text { R } & \text { K } & N & R & I & L & A & L & F & V & L & S & L & G & L & L & S\end{array}$

1801 ATTTATGGTAACGCCAGTGTCGGCAGCGTCAAAAGGAAACCTGCTGTCACCTGACCGTATCCTGACCGTCGCGCACAGAGGGGCTTCTGGATATGTGCCT

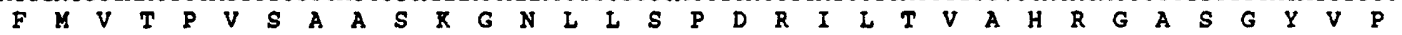

1901 GAGCACACGATTCTGTCTTACGAACCGCTCAGAAATGAAAGCTGATTTTATTGATTGGATCTGCAAATGACAAAAGACGAAATIGATTGTCATGC

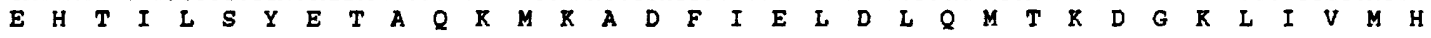

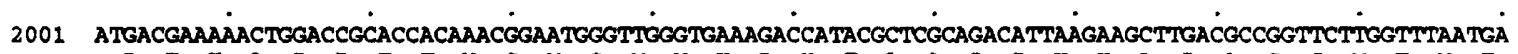

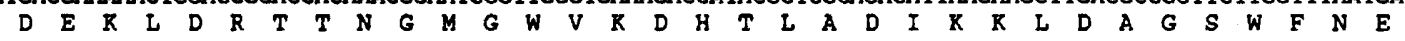

2101 AGCCTATCCGGAAAAAGCAAAGCCGCAGTACGTCGGCCTTAAAGTTCCTACATTAGAAGAGGTATTAGACCGTTTCGGAAAGCACGCGAACTACTACATT $\begin{array}{lllllllllllllllllllllllllllllllll}A & Y & P & E & R & A & K & P & Q & Y & V & G & L & K & V & P & T & L & E & E & V & L & D & R & F & G & K & H & A & N & Y & Y & I\end{array}$

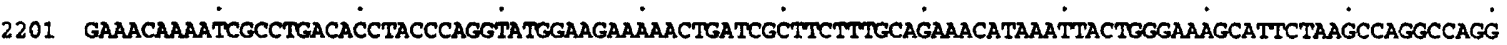

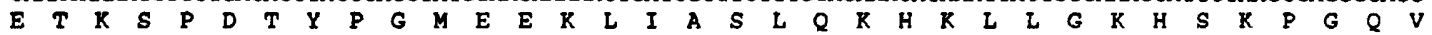

2301 TGATCATTCAATCGTTCAGCAAAGAAAGCCTGGTAAAAGTCCATCAATTACAGCCAAACCTGCCGACCGTTCAATTGCTGGAaGCCAAACAAATGGCGTC $\begin{array}{lllllllllllllllllllllllllllllllllllll}I & I & Q & S & F & S & K & E & S & L & V & K & V & H & Q & L & Q & P & N & L & P & T & V & Q & L & L & E & A & K & Q & M & A & S\end{array}$

2401 AATGACAGATGCTGCCCTGGAAGAAATCAAAACATACGCTGTCGGTGCGGGCCCGGATTATAAAGCTTTAAATCAAGAAAACGTCCGTATGATCCGCAGC $\begin{array}{llllllllllllllllllllllllllllllllll}M & T & D & A & A & L & E & E & I & K & T & Y & A & V & G & A & G & P & D & Y & K & A & L & N & Q & E & N & V & R & M & I & R & S\end{array}$

2501 CACGGCTCCTGCTTCATCCTTACACAGTCAATAATGAGCTGATATGCATCGCCTGCTTGATTGGGGCGTAACAGGAGTGTTCACCAACTATCCTGATC

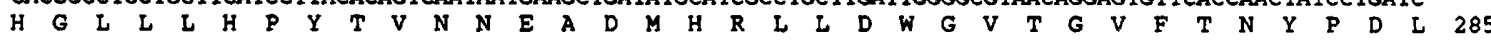

2601 TTITCCACAAAGTAAAAAAGGGTTATTAAAAGCAAAAAACCTTGCGACAACTATCGCAAGGIITITCTTCTATATTTTATTCTTMTCCGGCAGCAGCTTCT $F \quad H \quad R \quad V \quad K \quad X$ G $Y$ * * E K G A A A E

GACTGTCCATTAAGCKUET:

$S$ Q G N L TRF?

Fig. 2. For legend see facing page. 


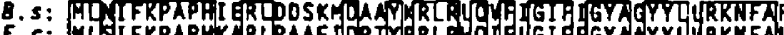

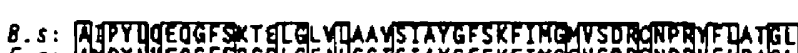

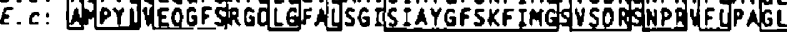

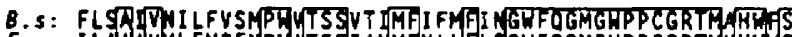

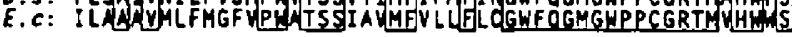

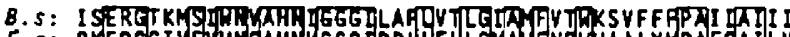

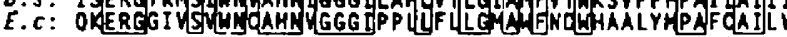

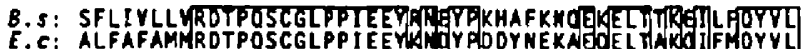

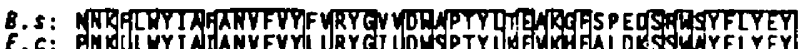

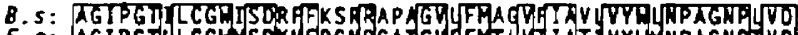

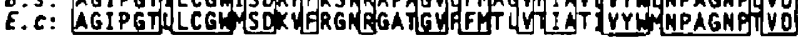

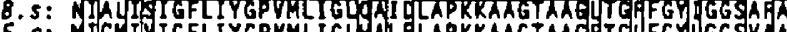

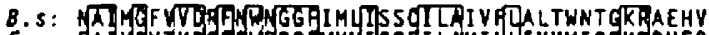

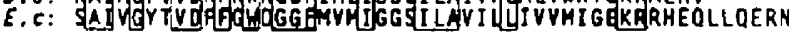

E.c: $G G$

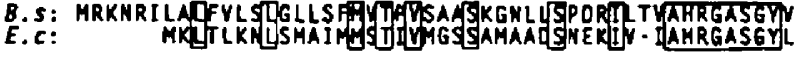

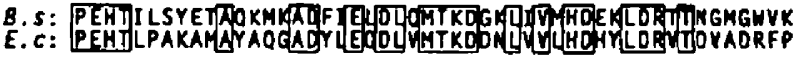

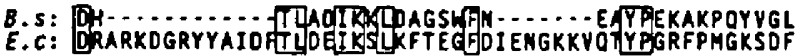

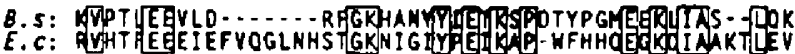

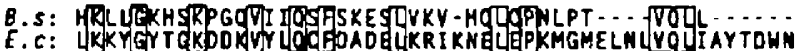

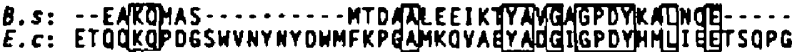

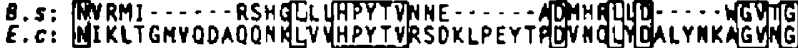

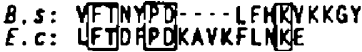

Fig. 3
Fig. 4

\begin{abstract}
Fig. 3. Comparison between the amino acid sequences of the deduced product of the $B$. subtilis g/p $T$ gene ( $B . s)$ and the $E$. coli GIpT protein (E.C). Identical amino acids are boxed. The identity between the two sequences is $60 \%$. When considering conserved amino acid substitutions, the similarity is $80 \%$, as determined with the Bestfit program (Devereux et al., 1984).
\end{abstract}

Fig. 4. Comparison between the amino acid sequences of the deduced product of the $B$. subtilis glpQ gene (B.s) and the $E$. coli GlpQ protein (E.C). Identical amino acids are boxed. Dashes represent gaps inserted to optimize the sequence alignment. The identity between the two sequences is $37 \%$. When considering conserved amino acid substitutions, the similarity is $63 \%$, as determined with the Bestfit program (Devereux et al., 1984).

inverted repeat) upstream of $g / p l)$ and $g / p F K$, respectively, has been demonstrated (Holmberg \& Rurberg. 1991, 1992; Heijer et al, 1993). It secms justified to assume that the inverted repcat upstream of g/p $\Gamma$ is important for control ot $g / p \%$ and $g / p Q$ expression.

i) second inverted repeat (position 26.36-266.5, Fig. 2) is located between glp $O$ and () Rt.3 and is not homologous to the inverted repeats upstream of $g / p T, g / p / K$ and $g / p l)$, respectively. However, it could function as a transcriptional terminator for transcripts originating both upstream and downstream of the repeat.

\section{Transcription of $g / p T$ and $g / p Q$}

The sigma A rype promoter preceding glp' $T$ is located on a $1.3 \mathrm{kh}$ : Vael cfolol fragment. This fragment was inserted 14 tront of the promoter-less $x / 1 \%$ gene in plasmid p.AMB22 to vield pl. 1 . 620 (Fig. 1). The identity and proper orientation of the fragment was verificd by sequencing. (cell extracts of $\mathrm{BR} 95 / \mathrm{p}+11 \mathrm{~B} 22$ have no) measurable (230 activity whereas exiracts of $\left.13 R^{9}\right) 5 /$ pl.LN620 have a measurable (2.30) activity which is 1.54 times higher when the cells are grown in the presence of glycerol or G3P. (jlucose represses the (:230) activity to a level below that found in extracts of uninduced cells irrespective of whether glycerol or ( $33 \mathrm{P}$ is also present in the growth medium (data not shown). This level of induction is comparable to that secn for induction of $g / p F K$ but lower than that for $g / t /)$ which has been shown to be about 15-fold (Beijer ef al., 1993; I Iolmberg \& Rutbers, 1991). In the following, the promoter driving expression of the $x /$ is gene in pl.t .11620 will be referred to as the glp $T$ promoter.

The $5^{\prime}$ end of the transcript initiated from the $g / p T$ promoter in pl.L M620 was mapped using nuclease S1. 'The probe used was a 346-nt-long $l$ ion R V-Kbal trayment

Fig. 2. Nucleotide sequence of $g / p T, g / p Q$ and part of ORF3 of 8 . subtilis. Both strands were sequenced and all restriction sites fully overlapped. Two potential rbs and a potential promoter sequence are underlined. Nucleotides conforming to the 'glucose repression sequence' are marked with $\wedge$. Inverted repeats are indicated with horizontal arrows. The transcriptional startpoint of g/pTQ is indicated with a vertical arrow. Left-margin numbers refer to the nucleotide sequence, right-margin to amino acid sequences. 

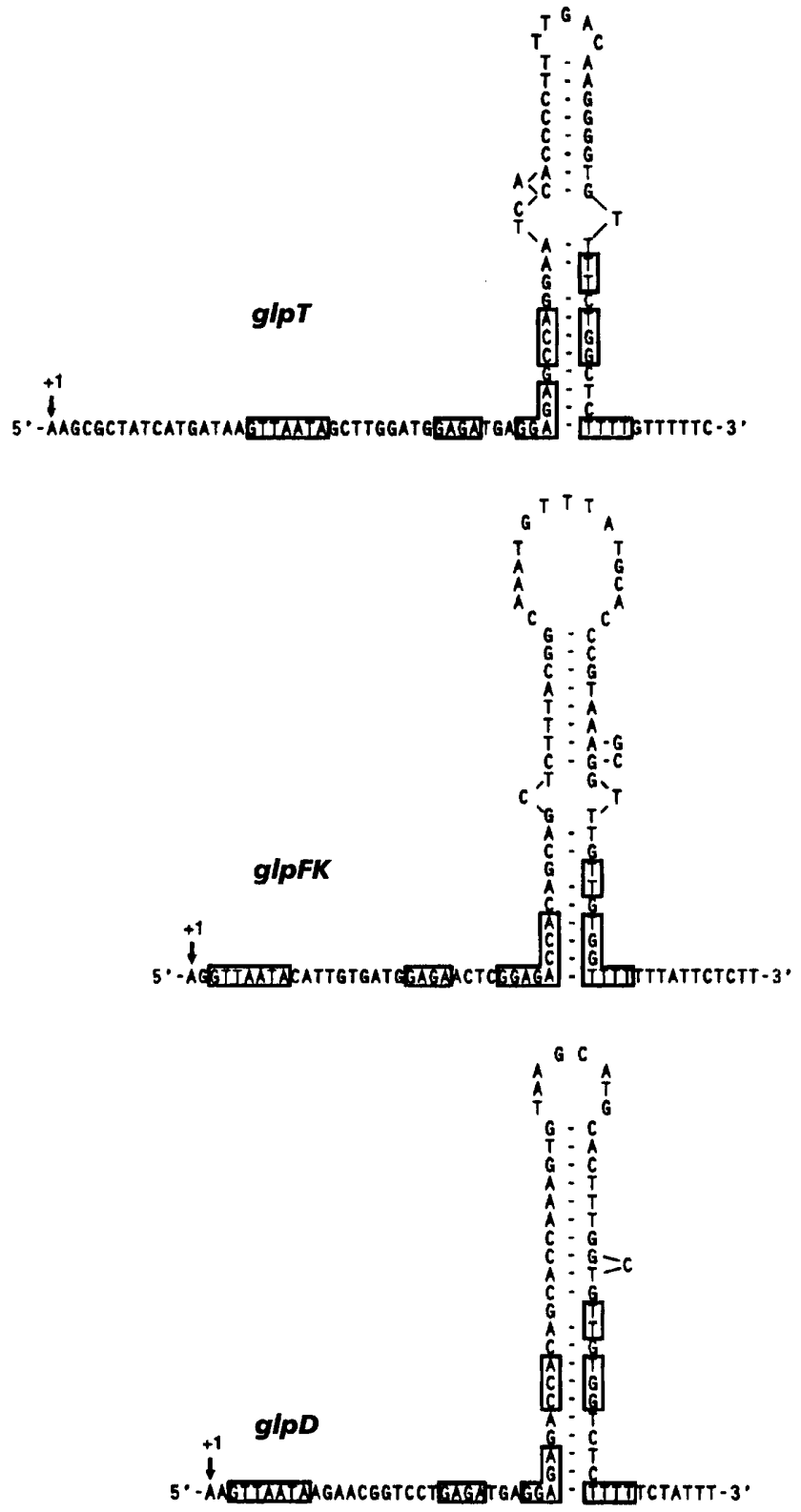

Fig. 5. The $g / p T Q, g / p F K$ and $g / p D$ inverted repeats. The inverted repeats are presented as stem-loop structures. Highly conserved regions are boxed.

which extends from upstream of the proposed -35 and -10 sequences of the $g l p T$ promoter and into the cloning cassette of pAMB22. This fragment (contained in pLUM621; Fig. 1) has a promoter activity similar to that found for pLUM620. The probe was labelled at the $5^{\prime}$ end. Since the $X b a I$ site originates from the pAMB22 cloning cassette, the experiment will only detect a transcript originating from pLUM620. Total RNA was extracted from BR95/pLUM620 grown with and without G3P. After hybridization with RNA from induced cells and treatment with nuclease $\mathrm{S} 1$, a protected fragment of $189 \mathrm{nt}$ was found (Fig. 6). The size of this fragment corresponds to a transcriptional start site at position 160 (Fig. 2).

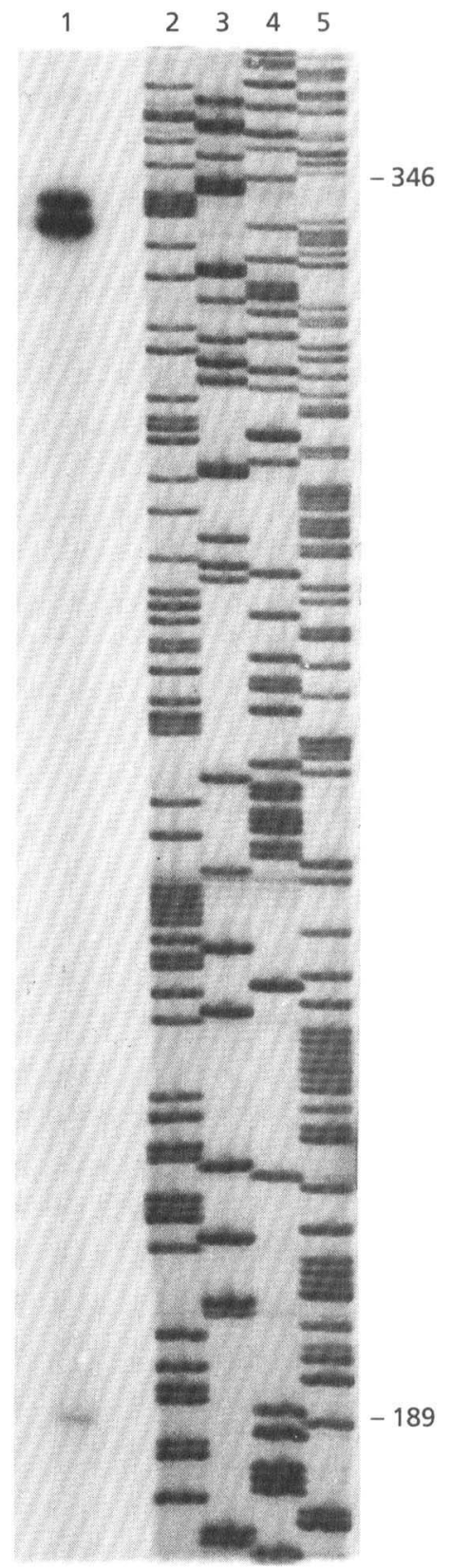

Fig. 6. Determination of the start of a transcript initiated from the g/pT promoter. Lane $1,10 \mu \mathrm{g}$ of total RNA from G3P. induced BR95/pLUM620, after nuclease S1 treatment. Lanes 2-5, standard, nucleotide sequence of a known DNA fragment.

The size of the transcript initiated from the $g l p T$ promoter in BR95 was determined in a Northern blot analysis (Fig. 7). Total RNA was extracted from cultures grown with or without G3P and probed with the $1 \mathrm{~kb}$ Pst $\mathrm{I}$ DNA fragment which is internal for $g l p T$ (Figs 1 and 2). A transcript of about $2600 \mathrm{nt}$ was detected which corresponds well to the expected size of a $g l p T Q$ transcript (about $2500 \mathrm{nt}$ ). The relative amount of this transcript was about threefold higher in RNA extracts from cultures grown in the presence of G3P. 


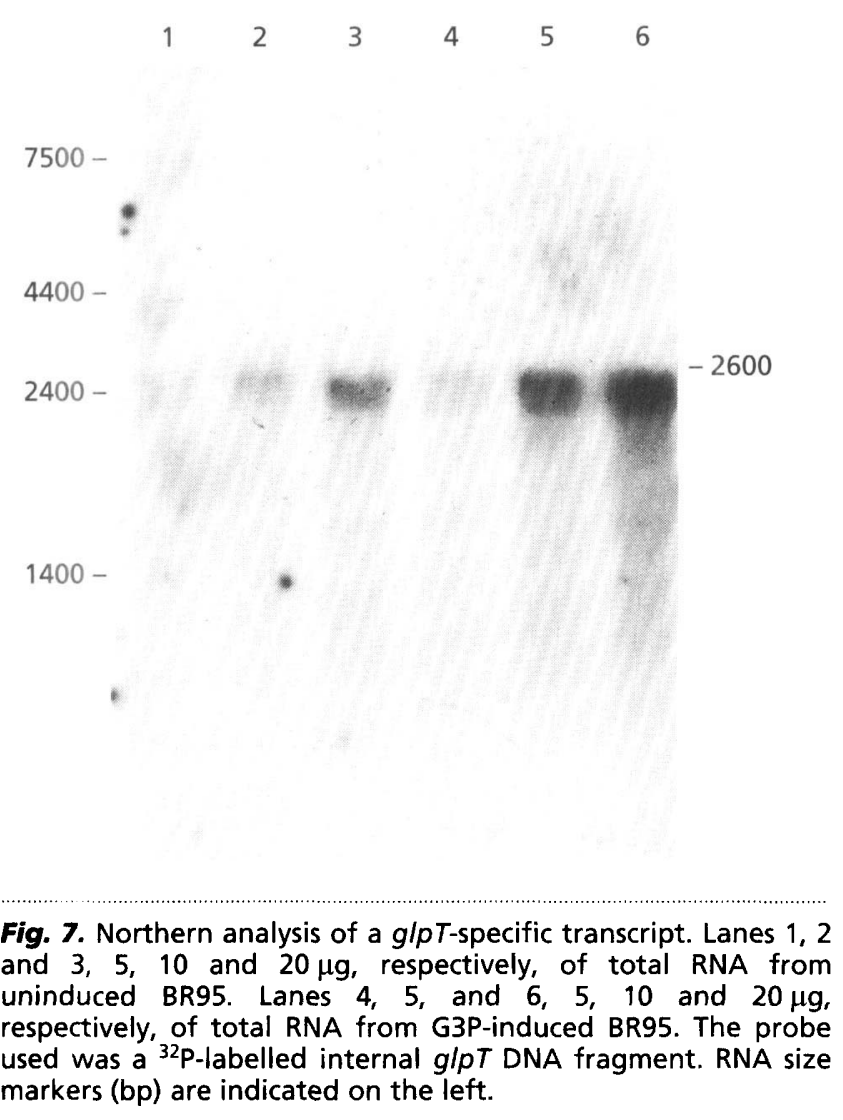

In conclusion, the primary structure of proteins involved in glycerol catabolism in B. subtilis and E. coli is highly conserved. The transcriptional organization of the corresponding genes is also similar; $g l p F K, g l p D$ and $g l p T Q$ are organized in separate operons. In contrast, although the glp genes are induced by G3P and repressed by glucose in both organisms, the mechanisms of control seem quite different. This has been observed also for other genes in carbohydrate catabolism in $B$. subtilis and $E$. coli (Steinmetz, 1993).

\section{ACKNOWLEDGEMENTS}

This work was supported by grants from the Swedish Medical Research Council, Emil and Wera Cornells Stiftelse and Magn Bergvalls Stiftelse. We thank Mrs Ingrid Stål for expert technical assistance and Lars Rutberg for valuable advice in preparing the manuscript.

\section{REFERENCES}

Amann, E., Brosius, J. \& Ptashne, M. (1983). Vectors bearing a hybrid trp-lac promoter useful for regulated expression of cloned genes in Escherichia coli. Gene 25, 167-178.

Anagnostopoulos, C. \& Spizizen, J. (1961). Requirements for transformation in Bacillus subtilis. J Bact 81, 741-746.

Arwert, F. \& Venema, G. (1973). Transformation in Bacillus subtilis. Mol \& Gen Genet 123, 185-198.

Ausubel, F. M., Brent, R., Kingston, R. E., Moore, D. D., Seidman, J. G., Smith, J. A. \& Struhl, K. (1987). Minipreps of Plasmid DNA.
In Current Protocols in Molecular Biology 1.6, 1.6.4-1.6.5. New York: John Wiley \& Sons.

Beijer, L., Nilsson, R.-P., Holmberg, C. \& Rutberg, L. (1993). The $g l p P$ and $g l p F$ genes of the glycerol regulon in Bacillus subtilis. J Gen Microbiol 139, 349-359.

Brzoska, P., Schweizer, H., Argast, M. \& Boos, W. (1987). ugpdependent transport system for sn-glycerol 3-phosphate of Escherichia coli. In Phosphate Metabolism and Cellular Regulation in Microorganisms, pp. 170-177. Edited by A. Torriani-Gorini and others. Washington, DC: American Society for Microbiology.

Crutz, A.-M., Steinmetz, M., Aymerich, S., Richter, R. \& Le Coq, D. (1990). Induction of levansucrase in Bacillus subtilis; an antitermination mechanism negatively controlled by the phosphotransferase system. J Bacteriol 172, 1043-1050.

Débarbouillé, M., Arnaud, M., Fouet, A., Klier, A. \& Rapoport, G. (1990). The $\operatorname{sac} T$ gene regulating the $\operatorname{sac} P A$ operon in Bacillus subtilis shares strong homology with transcriptional antiterminators. J Bacteriol 172, 3966-3973.

Devereux, J., Heberli, P. \& Smithies, O. (1984). A comprehensive set of sequence analysis programs for the VAX. Nucleic Acids Res 12, 387-395.

Eiglmeier, K., Boos, W. \& Cole, S. (1987). Nucleotide sequence and transcriptional startpoint of the glp $T$ gene of Escherichia coli: extensive sequence homology of the glycerol-3-phosphate transport protein with components of the hexose-6-phosphate transport system. Mol Microbiol 1, 251-258.

Garen, A. \& Levinthal, C. (1960). A fine-structure genetic and chemical study of the enzyme alkaline phosphatase of E. coli. I. Purification and characterization of alkaline phosphatase. Biochim Biopbys Acta 38, 470-483.

Gött, P. \& Boos, W. (1988). The transmembrane topology of the $s n$ glycerol-3-phosphate permease of Eschericbia coli analysed by pho $A$ and lac $Z$ protein fusions. Mol Microbiol 2, 655-663.

Gross, C. A., Lonetto, M. \& Losick, R. (1992). Bacterial sigma factors. In Transcriptional Regulation, pp. 129-176. Edited by S. L. McKnight \& K. R. Yamamoto. Cold Spring Harbor, NY: Cold Spring Harbor Laboratory.

Haima, P., Bron, S. \& Venema, G. (1987). The effect of restriction on shotgun cloning in Bacillus subtilis Marburg. Mol \& Gen Genet 209, 335-342.

Holmberg, C. \& Rutberg, B. (1989). Cloning of the glycerol kinase gene of Bacillus subtilis. FEMS Microbiol Lett 58, 151-156.

Holmberg, C. \& Rutberg, B. (1991). Expression of the gene encoding glycerol-3-phosphate dehydrogenase $(g l p D)$ in Bacillus subtilis is controlled by antitermination. Mol Microbiol 5, 2891-2900.

Holmberg, C. \& Rutberg, L. (1992). An inverted repeat preceding the Bacillus subtilis glpD gene is a conditional terminator of transcription. Mol Microbiol 6, 2931-2938.

Holmberg, C., Beijer, L., Rutberg, B. \& Rutberg, L. (1990). Glycerol catabolism in Bacillus subtilis: nucleotide sequence of the genes encoding glycerol kinase $(g / p K)$ and glycerol-3-phosphate dehydrogenase ( $g l p D)$. J Gen Microbiol 136, 2367-2375.

Houman, F., Diaz-Torres, M. R. \& Wright, A. (1990). Transcriptional antitermination in the $b g /$ operon of $E$. coli is modulated by a specific RNA binding protein. Cell 62, 1153-1163.

Larson, T. J. (1987). glp T-dependent transport of sn-glycerol 3phosphate in Escherichia coli K-12. In Phosphate Metabolism and Cellular Regulation in Microorganisms, pp. 164-169. Edited by A. Torriani-Gorini and others. Washington, DC: American Society for Microbiology.

Lin, E. C. C. (1987). Dissimilatory pathways for sugars, polyols, and carboxylates. In Escherichia coli and Salmonella typhimurium: Cellular 
and Molecular Biology, vol. 1, pp. 244-284. Edited by F. C. Neidhardt and others. Washington, DC: American Society for Microbiology.

Lindgren, V. (1978). Mapping of a genetic locus that affects glycerol-3-phosphate transport in Bacillus subtilis. J Bacteriol 133, $667-670$.

Lindgren, V. \& Rutberg, L. (1974). Glycerol metabolism in Bacillus subtilis: gene-enzyme relationships. J Bacteriol 119, 431-442.

Maloney, P., Ambudkar, S., Anantharam, V., Sonna, L. \& Varadhachary, A. (1990). Anion-exchange mechanisms in bacteria. Microbiol Rev 54, 1-17.

Mandel, M. \& Higa, A. (1970). Calcium-dependent bacteriophage DNA infection. $J$ Mol Biol 53, 159-162.

Marmur, J. (1961). A procedure for the isolation of deoxyribonucleic acid from micro-organisms. J Mol Biol 3, 208-218.

Nagarajan, V. (1993). Protein secretion. In Bacillus subtilis and other Gram-positive Bacteria, pp. 713-726. Edited by A. L. Sonenshein and others. Washington, DC: American Society for Microbiology.

Niaudet, B., Goze, A. \& Erlich, S. D. (1982). Insertional mutagenesis in Bacillus subtilis: mechanism and use in gene cloning. Gene 19, $277-284$

Resnekov, O., Rutberg, L. \& von Gabain, A. (1990). Changes in the stability of specific mRNA species in response to growth stage in Bacillus subtilis. Proc Natl Acad Sci US A 87, 8355-8359.

Sala-Trepat, J. M. \& Evans, W. C. (1971). The meta cleavage of catechol by Azotobacter species. Eur J Biochem 20, 400-413.

Sambrook, J., Fritsch, E. F. \& Maniatis, T. (1989). Preparation of radiolabeled DNA and RNA probes. In Molecular Cloning: $A$ Laboratory Manual 10, 10.60-10.61, 2nd edn. Cold Spring Harbor, NY : Cold Spring Harbor Laboratory.
Sanger, F., Nicklen, S. \& Coulson, A. R. (1977). DNA sequencing with chain-terminating inhibitors. Proc Natl Acad Sci USA 74, 5463-5467.

Schweizer, H., Boos, W. \& Larson, T. J. (1985). Repressor for the $s n$ glycerol-3-phosphate regulon of Escherichia coli K-12: cloning of the $g l p R$ gene and identification of its product. $J$ Bacteriol 161, $563-566$.

Steinmetz, M. (1993). Carbohydrate catabolism: pathways, enzymes, genetic regulation, and evolution. In Bacillus subtilis and other Gram-positive Bacteria, pp. 157-170. Edited by A. L. Sonenshein and others. Washington, DC: American Society for Microbiology.

Tommassen, J., Eiglmeier, K., Cole, S. T., Overduin, P., Larson, T. J. \& Boos, W. (1991). Characterization of two genes, $g l p Q$ and $u g p Q$, encoding glycerophosphoryl diester phosphodiesterases of Eschericbia coli. Mol \& Gen Genet 226, 321-327.

Truniger, V., Boos, W. \& Sweet, G. (1992). Molecular analysis of the glpFKX regions of Escherichia coli and Shigella flexneri.J Bacteriol 174, 6981-6991.

Weickert, M. J. \& Chambliss, G. H. (1990). Site-directed mutagenesis of a catabolite repression operator sequence in Bacillus subtilis. Proc Natl Acad Sci US A 87, 6238-6242.

Young, M. (1984). Gene amplification in Bacillus subtilis. J Gen Microbiol 130, 1613-1621.

Zukowski, M. M. \& Miller, L. (1986). Hyperproduction of an intracellular heterologous protein in a sac $U^{\text {h }}$ mutant of Bacillus subtilis. Gene 46, 247-255.

Received 6 September 1993; revised 21 October 1993; accepted 25 October 1993. 